\title{
Who's Got the Balance? A Study of Satisfaction with the Work-Family Balance among Part-Time Service Sector Employees in Five Western European Countries*
}

\author{
Barbara Beham, Patrick Präg, and Sonja Drobnič
}

2012

\begin{abstract}
Working part-time is frequently considered a viable strategy for employees to better combine work and non-work responsibilities. The present study examines differences in satisfaction with the work-family balance (SWFB) among professional and non-professional part-time service sector employees in five western European countries. Part-time employees were found to be more SWFB than full-time employees even after taking varying demands and resources into account. However, there are important differences among the part-timers. Employees in marginal part-time employment with considerably reduced working hours were the most satisfied. Professionals were found to profit less from reduced working hours and experienced lower levels of SWFB than non-professionals. No significant differences in SWFB were found between male and female part-time workers.
\end{abstract}

\section{Introduction}

Helping employees to reach a satisfactory balance between work and personal life has become an important issue in human resource management in recent years because work-family balance (WFB) has been associated with greater employee

\footnotetext{
*Published in 2012 in International Journal of Human Resource Management 23(18), pp. 3725-41, doi:10.1080/09585192.2012.654808.

Research for this study was partly supported by the European Commission through funding of the cross-national collaborative research project 'Quality of Life in a Changing Europe' (Bäck-Wiklund et al., 2011), within which the data were collected. The authors would like to thank co-researchers in the 'Quality' project as well as the Work and Organizations research group at the University of Groningen and an anonymous IJHRM reviewer for very helpful comments on an earlier draft of this article.
} 
commitment and job satisfaction (Carlson et al., 2009). The absence of balance, typically conceived of as high levels of conflict between work and non-work domains, has been associated with higher turnover intentions and absenteeism, and lower employee performance (see Eby et al., 2005, for an overview). Organizations have implemented policies and practices which provide employees with more flexibility and autonomy in managing their work and non-work responsibilities. In this context, part-time work is often regarded as essential to achieving a balance between work and family life and is advocated by national governments and the European Union. In many European countries, working reduced hours has become a customary strategy for combining paid employment and family responsibilities, especially for women with young children (Gasparini et al., 2000). However, part-time work appears in many forms and variations. The proportion of part-time workers and the characteristics of part-time jobs vary between countries, industrial sectors and occupations (Sándor, 2011). Part-time work also plays different roles for different employee groups. On the one hand it has been treated as a non-standard, precarious type of employment for less qualified employees (Tilly, 1996; Kalleberg, 2000), on the other hand it may be considered a win-win solution for professional employees and employers which facilitates employees' WFB, keeps women in the labor market instead of leaving it (and thus preserves human capital) and increases employment flexibility (Mills and Täht, 2011; Tomlinson, 2007). Implemented as an organizational policy to improve employees' WFB, part-time work is thought to provide employees with more convenient working hours, decrease conflict, stress and exhaustion, and enable them to better meet their personal and family responsibilities (Barnett and Gareis, 2002; Hakim, 2004). However, empirical studies about part-time work and WFB have reported inconsistent findings. Whereas research among professional women in high-level jobs reported a positive link between part-time employment and their WFB (Hill et al., 2004a,b), reduced working hours have been found to have negative implications for the work-life balance of workingclass employees (Lautsch and Scully, 2007).

The present study aims at providing insight into the relationship between part-time employment and WFB from a European perspective. Drawing on the scarcity (also referred to as resource drain or depletion) argument in work-family research (Edwards and Rothbard, 2000; Goode, 1960; Greenhaus and Beutell, 1985), the present study examines part-time employees' satisfaction with their work-family balance (SWFB) in service sector organizations in five western European countries (Sweden, the United Kingdom, The Netherlands, Germany, and Portugal). According to official statistics, part-time work is dominated by women and the largest proportion of part-time workers in the European Union is employed in the lower-grade and lower-paid occupations, predominantly in service sector industries (Sándor, 2011). In practice, part-time schedules are 
very heterogeneous, ranging from work hours long enough to almost be classified as full-time to a very short schedule of just a few hours per week. However, academic scholars only recently started distinguishing between different types of part-time work in empirical studies (Martin and Sinclair, 2007; Wittmer and Martin, 2011a,b). Contributing to this new strand of research, the present study does not treat part-time workers as a homogeneous group but distinguishes between marginal and substantial part-time employees (Bielenski et al., 2002). In addition, we examine the differences between professional and non-professional as well as male and female part-time employees. Previous research on parttime work and the work-family interface has often focused on highly qualified women only (Higgins et al., 2000; Hill et al., 2004a,b), thereby neglecting that female employees in lower-level occupations and men may experience part-time employment very differently. Finally, our study also contributes to a growing branch of international work-family literature by investigating service sector employees' SWFB in a non-US study context, in which the majority of research on WFB has hitherto been conducted (Hill et al., 2004b; Tausig and Fenwick, 2001; Valcour, 2007) and in which the implications of working part-time (usually no entitlement to employee benefits such as health insurance for part-timers, a 24/7 economy with a high prevalence of night-shifts and other non-standard working hours, comparatively weak employment protection) are very different from the contexts we are studying.

To begin with, we introduce the construct of 'SWFB' and provide a brief overview of the corresponding literature. We then contrast the theoretical potential of part-time work to increase SWFB with inconsistent empirical findings, and suggest that variation in part-time working arrangements might be at the core of the problem. Then, a set of study hypotheses is developed and tested. The study concludes with a discussion of the results, study limitations, future research suggestions and practical implications.

\section{Satisfaction with work-family balance}

Despite its widespread use in both the popular and the academic press, the term 'work-family balance' is an underdeveloped concept in work-family literature (Carlson et al., 2009). Early definitions of the construct rest upon the assumption that WFB is an individual choice and a personal responsibility, thereby ignoring structural, cultural and gendered constraints and letting organizations and the state off the hook (Carlson et al., 2009; Greenhaus and Allen, 2011; Grzywacz and Carlson, 2007; Lewis et al., 2007; Ransome, 2007). In recent literature, WFB is conceived as a social construct that is shaped by both individual and contextual factors (Drobnič et al., 2010; Drobnič and Guillén Rodríguez, 2011; Präg et al., 2010). Consistent with role balance theory 
(Marks and MacDermid, 1996), Grzywacz and Carlson (2007) define WFB as the 'accomplishment of role-related expectations that are negotiated and shared between an individual and his or her role-related partners in the work and family domains' (p. 458). Furthermore, they suggest uncoupling accomplishment of role-related activities from effectiveness and satisfaction in definitions of WFB.

The present study focuses on the satisfaction component of WFB and examines employees' levels of SWFB. Valcour (2007) defined SWFB as 'individuals' assessments that they have adequate resources to effectively respond to the demands of their work and family roles' (p. 19). It is a unitary, holistic construct consisting of two components: A cognitive component, including an appraisal of a person's ability to meet multiple work and family demands, and an affective component, including positive feelings as a result of this appraisal (Valcour, 2007). SWFB was found to be negatively related to working hours, commuting time, job demands, career demands, job insecurity, and work-to-family conflict. It was positively related to job complexity, job control, and social support at work (Beham et al., 2010; Clarke et al., 2004; Szücs et al., 2011; Valcour, 2007).

\section{Part-time work and work-family balance}

Research on working hours and the work-family interface is mainly founded on the scarcity argument (Edwards and Rothbard, 2000; Goode, 1960; Greenhaus and Beutell, 1985). The scarcity argument posits that individuals have a finite amount of time available that can be devoted to multiple roles in life. Time devoted to work will not be available for engagement in the private domain. Hence, long working hours may create conflicts for employees, which may lead to a preference for shorter working time (Lautsch and Scully, 2007). The most frequently cited reason for a reduction in working hours by employees in the European Union is indeed the need to better combine work and family responsibilities (Bielenski et al., 2002). However, research investigating the impact of reduced working hours on work-family outcomes yielded ambiguous and sometimes contradicting findings. Whereas part-time employees were found to experience lower levels of role overload and work-to-family conflict and higher levels of WFB and work-family fit, part-time workers also reported more physical and mental health problems, a more traditional division of household responsibilities, less career satisfaction and opportunities, higher job and financial insecurity, lower marital quality, and even poorer work-life balance than full-timers (Barnett, 2003; Higgins et al., 2000; Hill et al., 2004a,b; Lautsch and Scully, 2007; Tausig and Fenwick, 2001; Van Rijswijk et al., 2004).

These inconsistent findings may partially be due to a number of methodological and conceptual problems, such as varying definitions of part-time and full-time work, different reasons for working part-time (voluntary vs. involun- 
tary part-time work), the varying nature of part-time jobs and differences in part-time employees' work and non-work role involvement (e.g. Barnett and Gareis, 2000; Martin and Sinclair, 2007). The ILO's Part-Time Work Convention defines a part-time worker as an 'employed person whose normal hours of work are less than those of comparable full-time workers' (ILO, 1994). However, this definition does not tell us how many hours per week constitute a part-time job because the number of hours per week considered full-time differs significantly between countries, professions or even activities. In addition, part-time employees (see Martin and Sinclair, 2007, for a typology of part-time employees) as well as part-time arrangements themselves are very heterogeneous, including working hours ranging from close to the full-time standard to just a few hours per week. Recent research found different groups of part-time employees to differ in job attitudes (e.g. job satisfaction, organizational commitment), levels of employment mobility and turnover intentions (Wittmer and Martin, 2011a,b).

To account for variations in part-time schedules, Bielenski et al. (2002) suggested distinguishing between marginal $(<20 \mathrm{~h}$ per week) and substantial $(20-$ $34 \mathrm{~h}$ per week) part-time work. In line with the scarcity argument in workfamily research (Goode, 1960), we argue that working reduced hours may result in higher levels of SWFB for both marginal and substantial part-time employees, since part-time employees will be less involved in their work role than full-time employees, and have more time and energy to devote to their non-work responsibilities. However, we do expect employees in marginal part-time employment to have an advantage over those working a substantial part-time schedule because of less time commitment to the work domain and fewer organizational demands (e.g. time pressure and psychological job demands). Accordingly, we hypothesize the following.

Hypothesis 1. Both marginal and substantial part-time employment will be positively related to SWFB (a). The relationship will be stronger for marginal part-time employees (b).

We hypothesize that part-time employees are more SWFB. This may be due to less demanding, routine jobs and/or more flexible jobs which allow them to better attend to non-work responsibilities. In addition, part-time employees may work in an organizational environment that is particularly supportive of their family needs. By allowing employees to work part-time, organizations officially acknowledge and accept employees' non-work responsibilities and supervisors and colleagues may be more sensitive towards the family needs of these employees. In order to find out whether the positive relationship between parttime work and SWFB is due to part-time being prevalent in less demanding and/or more flexible jobs, several work demands (overtime hours, time pressure, psychological demands, job insecurity) and resources (social support at 
work, job control) are taken into account in our statistical analyses. Previous studies have shown that time-based work demands such as long working hours, overtime hours or organizational time pressure, as well as strain-based work demands such as psychological job demands and job insecurity decrease employees' SWFB, whereas work resources such as social support at work and job control increase employees' SWFB (Beham et al., 2010; Valcour, 2007).

\section{Professional status}

Work-family research has mainly focused on part-time work among professional employees, although there is empirical evidence that part-time work and its influence on employees' WFB are significantly different for non-professional workers (Lautsch and Scully, 2007). Low-skill part-time jobs tend to offer little job autonomy, inflexible working environments, limited career opportunities and less job and financial security (Barnett and Hall, 2001; Beham et al., 2014; Walsh, 2007). In addition, part-time employees in these kinds of jobs are often required to work irregular hours at the discretion of the employer (Lautsch and Scully, 2007; Wilson et al., 2008). These disadvantages of 'bad' part-time jobs may hamper part-time workers' ability to better manage their work and non-work responsibilities. Part-time jobs for professional employees, on the other hand, may offer appropriate salaries and opportunities for promotion, high levels of job autonomy and scheduling flexibility. Working part-time, at least temporarily, is increasingly regarded as an opportunity for professional employees with caring responsibilities to stay on the career track while gaining a desirable work-life balance. Empirical studies have in fact shown that professional women in high quality part-time arrangements reported a significantly greater WFB and less work-to-family conflict than their full-time working counterparts (Hill et al., 2004a,b; Van Rijswijk et al., 2004).

Whereas these previous studies have examined differences in work-life balance among part-time and full-time working professionals, we are interested in whether professional part-time employees differ in their experience of SWFB from part-time employees in non-professional jobs. Although high-status professional part-time arrangements may offer more resources (e.g. career opportunities, adequate pay, and high levels of job control and workplace flexibility) than non-professional part-time jobs, these resources may come at the expense of higher levels of time-based and strain-based job demands (Frone et al., 1992; Higgins et al., 2000). Professionals may experience more work pressure due to clients' demands that need to be satisfied and non-negotiable deadlines. Furthermore, professional work is fluid and less bound by time and space as compared with non-professional work, meaning that starting and finishing times as well as work sites can vary significantly (Lawrence and Corwin, 2003). These characteristics of professional work may increasingly blur the boundaries be- 
tween work and family/private life and lead to interference between these two life domains (Clark, 2000). A study among employees in Europe found that professional workers reported higher levels of conflict between work and family than non-professionals due to longer working hours and higher levels of work pressure (McGinnity and Calvert, 2009). Likewise, DiRenzo et al. (2011) found greater interference between work and family among higher level workers due to the more extensive job demands and work hours associated with higher level positions. In line with these findings, we expect that professional status will moderate the relationship between part-time employment and SWFB in such a way that professionals working part-time will be less satisfied with their WFB than part-time non-professionals.

Hypothesis 2. Professional status will moderate the relationship between part-time employment and SWFB. Professional parttime workers will be less SWFB than non-professional part-time employees.

\section{Gender}

Part-time employment in Europe is dominated by women. Whereas 31.9 per cent of employed women in the European Union worked part-time in 2010, only 8.7 per cent of employed men did so (Massarelli and Wozowczyk, 2010). Parttime work has become the preferred solution, especially for mothers, to combine paid employment and caring responsibilities (Sándor, 2011). They frequently use part-time work as a temporary alternative to full-time employment or leaving the labor market entirely (Buddelmeyer et al., 2005). Despite changing gender role attitudes, gendered behavior in contemporary societies persists: work is men's business and family is women's domain. Women continue to be primarily responsible for childcare and housework and spend more time in the family role, while men dedicate more time and effort to the work role (Treas and Drobnič, 2010). In addition, the norm of the 'ideal worker' (Acker, 1990), who is fully devoted to work, works long hours, has no family responsibilities, and thus requires minimal accommodation for personal life, is still very much in place in contemporary workplaces. Women can hardly approximate to this male norm of work due to their involvement in unpaid housework and care work (Webber and Williams, 2008). Those trying to simultaneously juggle long working hours and non-work responsibilities may be caught in a 'time bind' (Hochschild, 1997), and experience pressure and tensions as a consequence of incompatible demands from work and non-work (Greenhaus and Beutell, 1985). A reduction in working hours may free time for non-work responsibilities, provide women with more flexibility and consequently increase their ability to reach a satisfying equilibrium between work and family demands. Men's explanations for 
working part-time are rarely their family responsibilities. Men are more likely to be in involuntary part-time employment (due to the fact that they could not find a full-time job), and they more often combine part-time work with education than women (Eurostat, 2009). Accordingly, we hypothesize the following.

Hypothesis 3. Gender will moderate the relationship between parttime employment and SWFB. Women working part-time will be more SWFB than men working part-time.

\section{Methods}

\section{Procedure and participants}

Survey data were collected among service sector employees in Sweden, the United Kingdom, The Netherlands, Germany, and Portugal as part of a larger collaborative research project funded by the European Commission (Bäck-Wiklund et al., 2011). In each country, part-time and full-time employees working in four different service sector organizations were surveyed. These organizations were in financial services, information and communication technology, health care and retail. Thus, our sample comprises service sector employees in twenty different organizations in five western European countries.

The questionnaire was developed by the research team in English and was translated into the national languages of the participating countries using Brislin's (1986) back-translation method. Pilot studies were conducted prior to data collection in each country. Data were collected by means of both online surveys and paper and pencil questionnaires. Response rates in these twenty organizations ranged from 20 per cent to 79 per cent. Further descriptions of the data can be found in Präg et al. (2011).

Table 1 gives an overview of the sample composition. The total sample comprises 4,476 part-time and full-time employees. Country samples range from 592 employees in Sweden to 1,137 employees in Portugal, with female survey participants forming the majority in the sample. Among the participants of the study, 70.5 per cent were married or have a partner and participants are on average 40.7 years old.

The distribution of part-time workers in this sample of service sector employees closely reflects the official statistics on part-time employment in Europe (Massarelli and Wozowczyk, 2010). The proportion of part-time workers is highest in the Netherlands (53.8 per cent), where part-time work has become the preferred flexible work arrangement to combine work and family responsibilities. In the literature, The Netherlands have also been referred to as the first part-time economy in the world (Visser, 2002). Part-time work is less common in Germany (25.9 per cent), Sweden (23.8 per cent) and the United Kingdom 
Table 1: Overview of the sample composition (percentages unless otherwise stated)

\begin{tabular}{|c|c|c|c|c|c|c|}
\hline Percentage & Sweden & United Kingdom & The Netherlands & Germany & Portugal & Total \\
\hline Men & 37.2 & 41.1 & 32.0 & 41.8 & 44.6 & 39.7 \\
\hline Women & 62.8 & 58.9 & 68.0 & 58.2 & 55.4 & 60.3 \\
\hline Age (mean) & 44.1 & 41.6 & 40.0 & 42.2 & 37.5 & 40.7 \\
\hline \multicolumn{7}{|l|}{ Family status } \\
\hline Married/partnered & 67.9 & 28.6 & 75.0 & 71.1 & 66.9 & 70.5 \\
\hline No. of children (mean) & 0.9 & 0.7 & 0.9 & 0.7 & 0.8 & 0.7 \\
\hline \multicolumn{7}{|l|}{ Work status } \\
\hline Full-time & 76.2 & 77.1 & 46.2 & 74.1 & 96.3 & 74.5 \\
\hline $\begin{array}{l}\text { Part-time } \\
\text { of which: }\end{array}$ & 23.8 & 22.9 & 53.8 & 25.9 & 3.7 & 25.5 \\
\hline Women & 84.4 & 86.5 & 89.8 & 93.6 & 62.8 & 88.6 \\
\hline Men & 15.6 & 13.5 & 10.2 & 6.4 & 37.2 & 11.4 \\
\hline Marginal & 11.3 & 27.0 & 20.9 & 15.5 & 69.8 & 21.1 \\
\hline Professional & 29.8 & 30.1 & 44.7 & 57.2 & 51.2 & 44.1 \\
\hline \multicolumn{7}{|l|}{ Industry } \\
\hline Retail & 16.7 & 22.6 & 29.1 & 12.7 & 27.0 & 30.5 \\
\hline $\mathrm{ICT}$ & 31.3 & 32.4 & 21.9 & 45.0 & 22.0 & 21.9 \\
\hline Health care & 22.0 & 20.9 & 30.2 & 24.8 & 12.6 & 21.8 \\
\hline Finance & 30.1 & 24.1 & 18.8 & 17.5 & 38.4 & 25.8 \\
\hline$N$ & 592 & 713 & 944 & 1,090 & 1,137 & 4,476 \\
\hline
\end{tabular}

Notes: Marginal part-time employment is less than 20 contracted hours per week. 
(22.9 per cent), but is still above the European average. It is lowest in Portugal with only 3.7 per cent of our study participants working a part-time schedule. In all five countries, national regulations for part-time work are in place, according to which either all employees contingent on the size of the company (e.g. Germany and The Netherlands) or at least parents with young children (e.g. United Kingdom, Portugal, and Sweden) are entitled to reduce their working hours (Sándor, 2011).

Not surprisingly, the majority of part-time workers in this sample are women (88.6 per cent), with proportions of male part-time workers ranging from 6.4 per cent in Germany to 37.2 per cent in Portugal. With the exception of Portugal, substantial part-time employment (20-34 h per week) is predominant in all countries. Marginal part-time employment $(<20 \mathrm{~h}$ per week) is lowest in Sweden (11.3 per cent) where most part-time employees work a substantial part-time schedule that is often close to a full-time schedule (Bielenski et al., 2002). The proportion of professional part-time employees ranges from 29.8 per cent in Sweden to 57.2 per cent in Germany.

\section{Measures}

SWFB was measured with three items on a five-point Likert scale $(1=$ very dissatisfied to $5=$ very satisfied) developed by Valcour (2007). An example item is 'How satisfied or dissatisfied are you with the way you divide your time between work and personal life?' Cronbach's alpha of the scale was 0.89 .

Full-time, substantial part-time and marginal part-time workers are distinguished by using two dummy variables, one for substantial part-time workers (1 $=20-34$ contracted hours per week, $0=$ other) and one for marginal part-time workers $(1=<20$ contracted hours per week, $0=$ other $)$. Accordingly, the group of full-time workers will serve as the reference category in our regression models. Professional status ${ }^{1}$ is dummy coded, with $1=$ professional and $0=$ non-professional. Gender is dummy coded with $1=$ female and $0=$ male.

Age, marital status, number of children in the household, household income, selected work demands and resources, and country-dummies (Germany is the reference category) were included as control variables in the statistical analyses. Marital status is dummy coded, with $1=$ married/cohabiting and $0=$ not married/cohabiting. Household income was measured on a twelve-point scale

\footnotetext{
${ }^{1}$ Survey participants provided the occupational title of their jobs. These descriptions were coded using the International Standard Classification of Occupations (ISCO 88), which was used together with the information on supervisor status and number of employees under supervision to assign participants to the Erikson-Goldthorpe-Portocarero (EGP) classes (Erikson and Goldthorpe, 1992). These classes, generally referred to as the EGP scheme, consist of eleven occupational groups allowing for comparative analyses between different employee categories. In our study, 'high and low controllers' were collapsed into a new category 'professionals'. The EGP classes 'routine non-manual', 'routine manual', 'skilled-manual', 'semi-unskilled manual', 'skilled manual' and 'manual supervisor' were classified as 'non-professionals'. We did not have self-employed, small employers and farm workers in our sample.
} 
$(1=<150$ Euro; $12=$ over 10,000 Euro per month). Overtime hours were calculated as the difference between actual and contracted working hours per week. Time pressure was measured with three items on a five-point Likert scale ( 1 = strongly disagree; $5=$ strongly agree) (Dikkers et al., 2004). Five items taken from the Swedish Demand-Control-Support Questionnaire were used to measure psychological demands at work (Sanne et al., 2005). Job insecurity was assessed with a four-item measure based on the work of Sverke et al. (2004) using a five-point Likert scale ( $1=$ strongly disagree; $5=$ strongly agree). Job control was measured with four items on a four-point scale ( $1=$ never; $4=$ always $)$ taken from Sanne et al. (2005) and Kossek et al. (2006). Work-family support from supervisors and co-workers was assessed with a six-item scale (Dikkers et al., 2004). Answers were made on a 5 -point Likert scale ( $1=$ strongly disagree; $5=$ strongly agree). Cronbach's alpha for several multi-item scales were above the cut-off criteria of 0.70 (see Table 2).

\section{Analytical strategy}

Our sample comprises 4,476 individuals working in twenty service sector organizations, which means that observations within one organization are not independent. To account for this nested data structure, hierarchical linear (random coefficient) modeling is recommended (Raudenbush and Bryk, 2002). We first estimated an empty, so-called 'null' model, which only includes the intercept without any predictors. This model allows us to calculate the intraclass correlation coefficient (ICC) by partitioning the total variance in the outcome variable SWFB into its within- and between-organization components and then calculating the proportion of variance accounted for by the organization level. The ICC for our null model is 0.047 , showing that organizations account for approximately five per cent of the variability in our outcome variable. According to the rule of thumb, hierarchical linear modeling is recommended if the ICC is at least 0.05. Gelman and Hill (2007), however, suggest that even when the ICC is low, hierarchical linear modeling yields more accurate regression coefficients and more correct standard errors than ordinary least square regressions. Furthermore, they recommend estimating hierarchical linear models even if the number of Level 2 units is small (e.g. twenty organizations). Accordingly, we used hierarchical linear models to test our study hypotheses.

\section{Results}

Descriptive statistics and Pearson's correlation coefficients for the study variables (without country dummies) are presented in Table 2.

Using hierarchical linear modeling, we estimated three random intercept models adding variables in each step. In these models, the regression lines of 


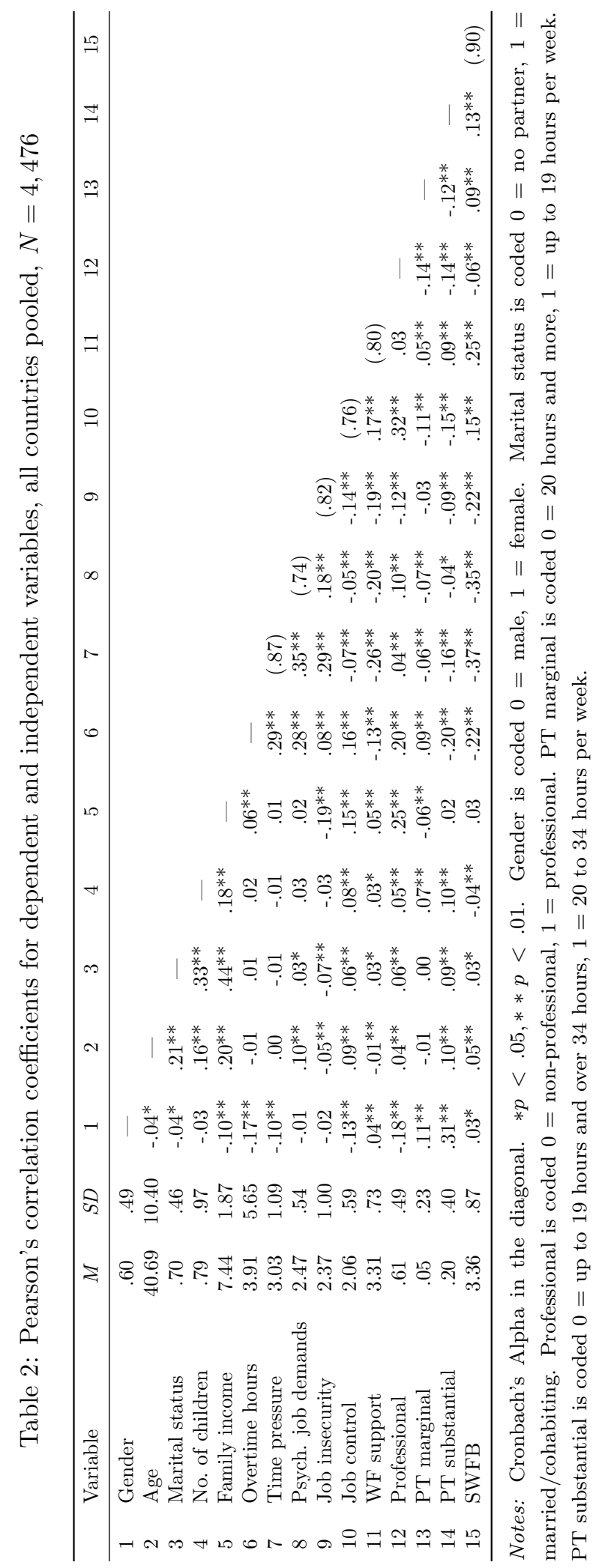


the level-2 units (i.e. organizations) were allowed to have different intercepts but were forced to have the same slope. Alternatively, we also tested random slope models allowing for organization-specific slopes (Gelman and Hill, 2007), but model fit did not improve significantly. Consequently, Table 3 reports coefficients of fixed effects and corresponding standard errors, deviance, ICC, and variance components of the random intercept models.

Model 1 only includes the two variables on part-time work, in Model 2 the moderators, control variables, and country dummies are added into the equation. Model 3 introduces four interaction terms (marginal part-time $\times$ professional status; substantial part-time $\times$ professional status; marginal part-time $\times$ gender; substantial part-time $\times$ gender) to test the moderating effects of professional status and gender on the relationship between part-time work and SWFB. Model 1 shows that both marginal $(\beta=0.35, p<0.01)$ and substantial part-time workers $(\beta=0.19, p<0.01)$ were more SWFB than full-time workers. Both regression coefficients remain significant even after controlling for various job demands and resources (Model 2). As predicted, the relationship was stronger for marginal part-time employees than for substantial part-time workers, which we confirmed with a $\chi^{2}$ test for differences between the coefficient sizes $\left(\chi^{2}=6.56, d f=1, p<0.01\right)$. Accordingly, Hypotheses $1 \mathrm{a}$ and $1 \mathrm{~b}$ were supported. Both moderator variables were significantly and negatively related to SWFB, meaning that professional employees and women were less SWFB than non-professional employees and men, respectively.

Examining the coefficients for the control variables revealed no significant country differences. The number of children was negatively related to WFB ( $\beta=-0.08, p<0.01)$, meaning that SWFB decreases if the number of children increases. Several job demands were significantly and negatively related to SWFB, whereas work resources were significantly and positively related to SWFB. These findings are in-line with previous empirical studies on SWFB (e.g. Abendroth and den Dulk, 2011; Beham and Drobnič, 2010; Valcour, 2007).

Hypothesis 2 posits that professional part-time employees will be less SWFB than non-professional part-time employees. Our analysis yielded significant interaction terms for both forms of part-time employment: $\beta=-0.29, p<0.01$ for marginal part-time and $\beta=-0.15, p<0.01$ for substantial part-time (Table 3, Model 3). Figure 1 displays a plot of predicted SWFB, taking the main effects as well as interactions with professional status into account. The plot shows that both professional and non-professional part-timers were more SWFB than full-timers. However, the difference was considerably smaller for professionals than non-professionals. Professional part-time employees experienced less SWFB than non-professional part-time workers, thereby confirming Hypothesis 2 . The difference between professional and non-professional part-time workers increases as working time decreases, resulting in a particularly pro- 
Table 3: Satisfaction with work-life balance: Results of the hierarchical linear models

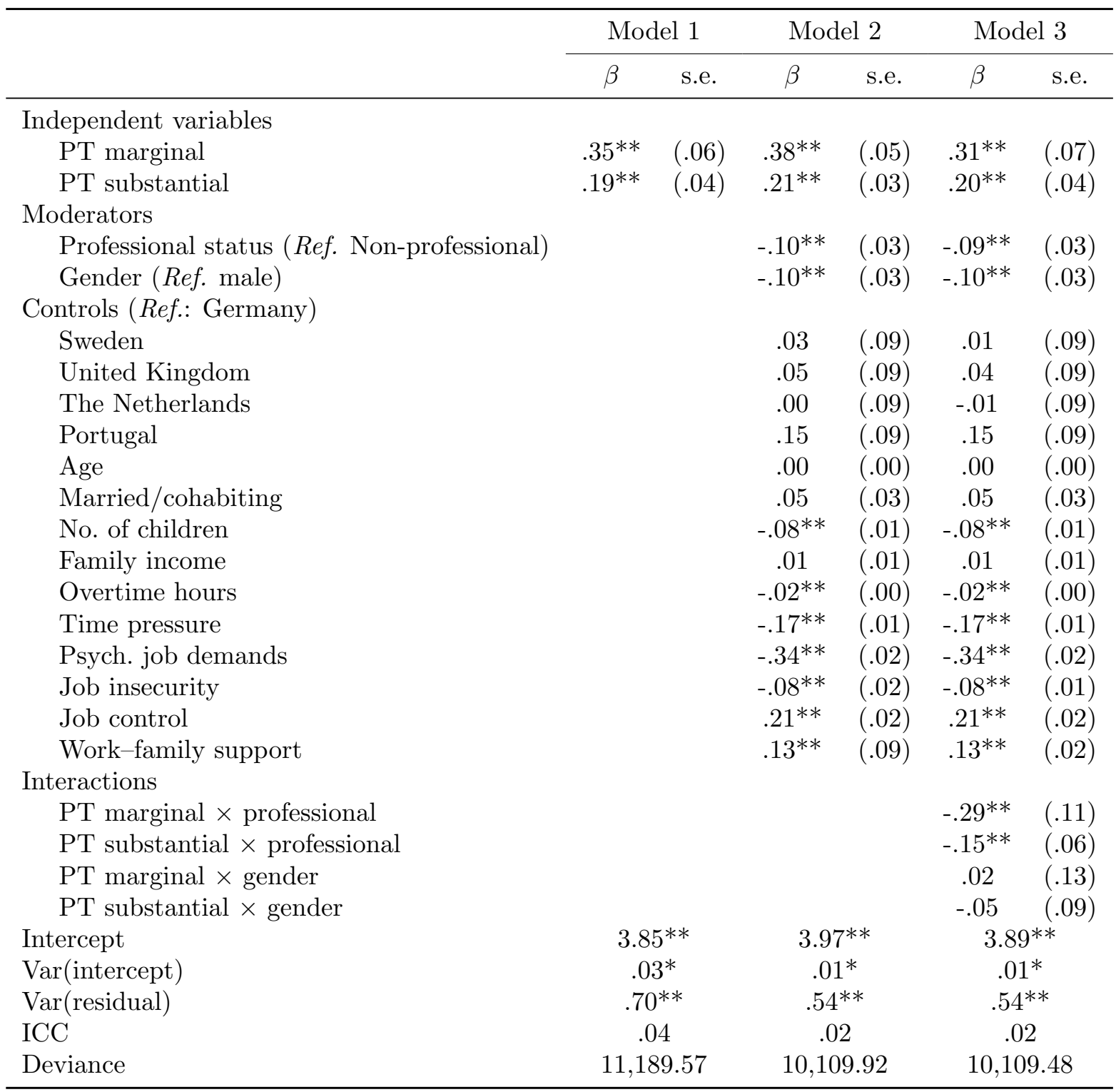

Notes: $* p<.05, * * p<.01$. All independent variables are grand mean centered 
nounced difference between professionals and non-professionals holding marginal part-time jobs.

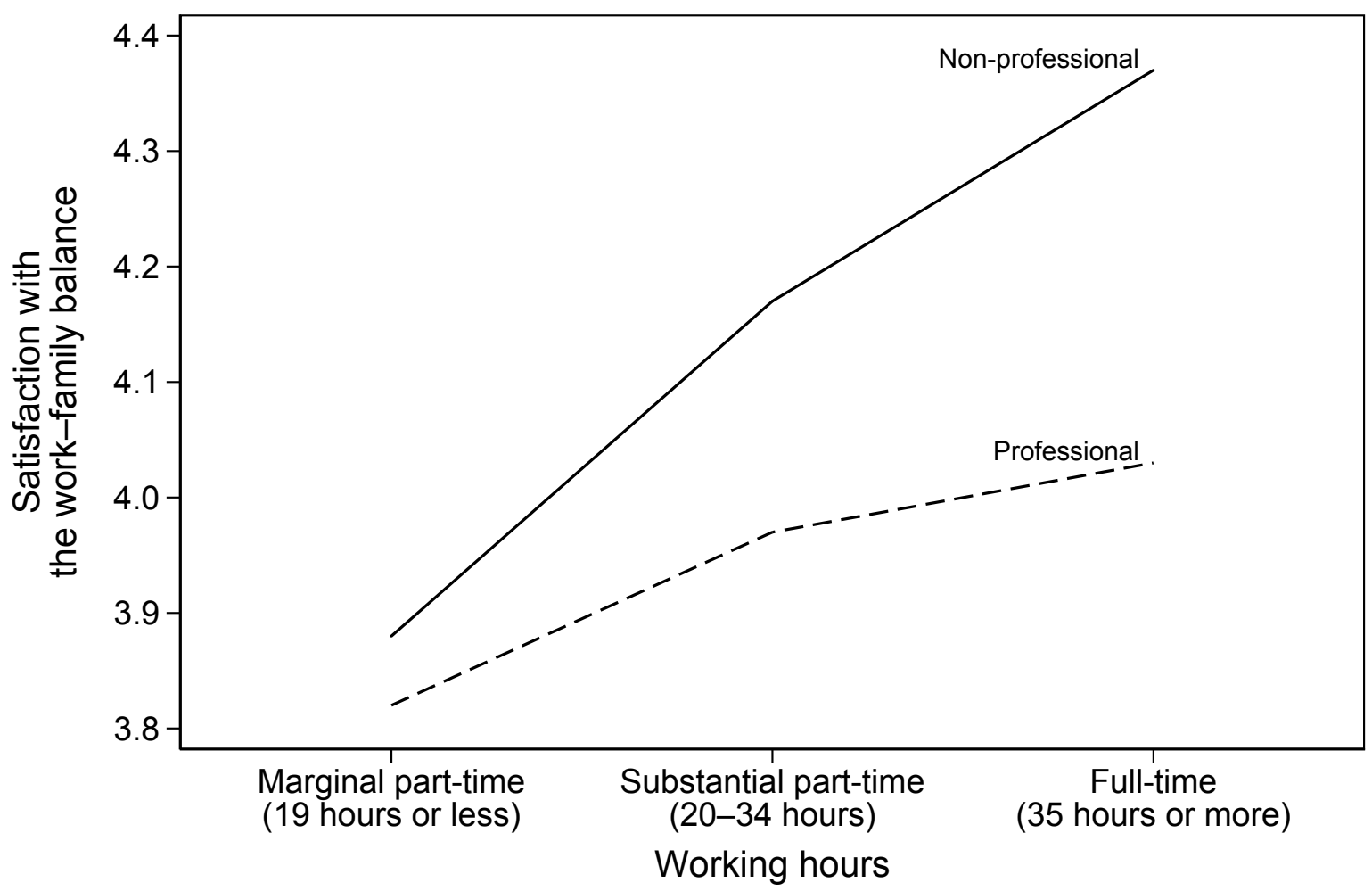

Figure 1: Interaction between part-time work and professional status as related to SWFB

With respect to the impact of gender, we found that women were less SWFB $(\beta=-0.10, p<0.01)$ than men. This corroborates existing knowledge about the unequal share of the burden of work and domestic responsibilities between men and women (Treas and Drobnič, 2010). However, contrary to our predictions we found no significant interaction of gender and part-time employment. In Hypothesis 3, we had posited that women should benefit more from working part-time than their male counterparts. But as Table 3 shows, women and men did not differ significantly in the positive effects of part-time work on SWFB. This finding also held true when no distinction was made between substantial and marginal part-timers $(\beta=-0.03, p=0.68$; analysis not shown $)$ and when the interactions between part-time work and gender were estimated separately from the interactions between part-time work and professional status. Accordingly, Hypothesis 3 was not supported. 


\section{Discussion}

The main purpose of this study was to analyze satisfaction with work-life balance among part-time service sector employees with varying part-time schedules, professional status and gender in five western European countries. Recent research suggested that part-time employees cannot be treated as a homogeneous group (Martin and Sinclair, 2007). To account for variation among part-time employees, we distinguished between marginal and substantial part-time employment (Bielenski et al., 2002). Our analysis revealed that part-time employees are more SWFB than full-time employees above and beyond of what it is accounted for by job demands and resources. The relationship is stronger for part-time employees working a marginal schedule of less than 20 hours per week than for those working a substantial part-time schedule of between 20 and 34 hours. Although part-time work may bring disadvantages in terms of pay, career prospects and benefits, these findings suggest that shorter working hours are beneficial for attaining a satisfactory work-life balance. Part-time workers who were able to substantially reduce their working hours are better able to attend to their non-work responsibilities and consequently report higher levels of SWFB.

The study further investigated whether differences in SWFB between fulltime and part-time employees can be found among both non-professional and professional workers. In an effort to retain highly qualified staff, especially women, organizations have begun to offer part-time employment options for professional workers and managers (Barnett and Hall, 2001). These arrangements aim to allow professionals to stay on the career track while achieving a satisfactory work-life balance. However, our research shows that professional part-time employees profit less from shorter working time than non-professionals (Figure 1). The difference between professional and non-professional part-timers is particularly large for employees in marginal part-time jobs below 20 hours per week. These findings could be due to the nature of professional work itself. As a rule, professionals do experience a substantial level of autonomy at their work place, which they acquire and sustain through their specific knowledge, training and social status within organizations. However, professional work is often not confined to rigid timetables, and employers frequently expect a high level of availability from their professional employees. Being called in for a meeting unexpectedly, and keeping in touch with clients, subordinates and colleagues during the negotiated times of absence are common for professional part-time employees (Lawrence and Corwin, 2003). Blurred boundaries between work and home, higher levels of interference between work and personal life, and less satisfaction with one's work-life balance may be the consequences. These effects may be even stronger when professionals work very short hours and try to squeeze the requirements of a demanding professional job into a marginal 
part-time schedule. Although we do account for a number of salient features of professional work (e.g. overtime, time pressure and job control), the differences between professionals and non-professionals persist and may be due to characteristics of professional work not fully depicted by our measures of work demands and resources (e.g. intensity of client contact and amount of face time required).

Contrary to our predictions, we did not find a significant moderating effect for gender. Since women still shoulder the majority of household and care work and often choose part-time jobs with the specific aim of reconciling work and family, we expected women to be more SWFB than their male counterparts if they work a reduced schedule. However, our findings did not reveal any differences between men and women, which is in accordance with a recent report issued by Sándor (2011). Using data from the European Working Conditions Survey, the report concludes that there are hardly any differences in satisfaction with work-life balance between men and women working part-time. Nevertheless, the findings of our study corroborate recent research on part-time employment that acknowledges differences in part-time schedules and diversity among part-time employees (Beham et al., 2011; Martin and Sinclair, 2007; Wittmer and Martin, 2011a,b).

\section{Limitations and future research suggestions}

Some limitations of this study should be kept in mind when interpreting the results. The design of the study was cross-sectional in all countries and all variables were self-reported by the study participants. Such a design does not allow for final causal conclusions and may be subject to common method bias. Although our findings are largely consistent with the assumed causal relationships outlined in the hypothesis section of this paper, rival explanations for significant relationships cannot be ruled out (Spector, 2002; Stone-Romero and Rosopa, 2007). Furthermore, the sample comprises service sector employees in certain industries, meaning that the results may not generalize to a larger population of workers. Future studies will definitively benefit from longitudinal designs and samples including a broader array of industries. In addition, our study does not take into account how voluntary a part-time work arrangement is. Outcomes for part-time workers may vary depending on whether the employee has opted for a part-time job voluntarily or was forced to work a reduced schedule because no other work was available (e.g. Tilly, 1996). Although involuntary part-time employment is at a very low level in The Netherlands, Germany, and the United Kingdom and at a moderate level in Sweden and Portugal according to official statistics (Buddelmeyer et al., 2005), future empirical research may want to take this aspect of part-time work into consideration. In addition, future studies on part-time work and the work-family interface should give even 
more depth to the issue of heterogeneity of part-time employment by including a more refined typology of part-time employees (e.g. the latest typology of Wittmer and Martin, 2011b).

\section{Practical implications}

Our findings indicate that working less than 20 hours per week has a stronger impact on employees' SWFB than a substantial part-time schedule of 20-34 hours per week. This is particularly true for non-professional employees who are more likely to perform routine tasks and for whom it is also easier to establish shorthour part-time positions. For professionals, who according to our results benefit less from reduced working hours, it is important to make their work-life priorities and schedules transparent to the organization. Transparent routines and procedures that facilitate an efficient flow of work when the part-time professional is off work need to be established between employees and employers (Corwin et al., 2001). In addition, the work demands and workloads of professionals need to be reduced accordingly if part-time work is to exert its positive impact on employee behavior (Lee et al., 2002) and SWFB.

However, organizations may be reluctant to offer marginal part-time jobs to professional employees because a substantial reduction in working hours may require a redesign of the job, a reallocation of tasks within the workgroup or department, or hiring and training a new employee who takes over the 'other half of the job'. Employers confronted with requests for marginal part-time employment from highly qualified, professional workers may consider job sharing a viable option to deal with such requests.

Finally, we want to clearly emphasize that organizations need to implement 'good' part-time jobs for both professional and non-professional workers which offer adequate pay, good working conditions and opportunities for advancement, and do not put them at a disadvantage compared to full-time employees. Part-time work frequently entails an 'occupational downgrading', meaning that employees change to lower level jobs when they switch from full-time to parttime work (Lyonette et al., 2010). After several years, these employees may be 'trapped' in these less qualified part-time jobs, and are perceived by their employers as having lost valuable human capital (Walters, 2005). Compared to the USA, the European Union has issued various directives to improve the working conditions of part-time workers. These EU Directives are part of European employment law and have been adopted by the member states. Satisfaction with working conditions among part-time employees is similar to that among full-time employees in the European Union, but there continue to be differences in prospects for career advancement, task complexity and access to training and development opportunities (Sándor, 2011) that need to be overcome in the future. 


\section{Conclusions}

Our study contributes to a new strand of research on part-time employment by pointing out the different nature of part-time work and its consequences for SWFB of both non-professional and professional employees. Furthermore, the findings add to the work-family literature by extending mainly US-based knowledge on SWFB and part-time employment to European service sector workers. Our results clearly demonstrate that research on part-time employment and the work-family interface should take differences among part-time employees into account. Likewise, human resource management professionals in organizations should treat part-timers as a heterogeneous rather than a homogeneous group of employees who differ in their experience of balancing work and non-work responsibilities.

\section{References}

Abendroth, Anja-Kristin and Laura den Dulk, 2011. 'Support for the Work-Life Balance in Europe. The Impact of State, Workplace, and Family Support on Work-Life Balance Satisfaction.' Work, Employment, and Society 25(2): 234-256. doi: 10.1177/0950017011398892.

Acker, Joan, 1990. 'Hierarchies, Jobs, Bodies. A Theory of Gendered Organizations.' Gender and Society 4(2): 139-158. doi: 10.1177/089124390004002002.

Barnett, Rosalind Chait, 2003. 'Reduced Hours Work/Part-Time Work.' In Kossek, Ellen and Marcie Pitt-Catsouphes, eds., Work and Family Encyclopedia. Chestnut Hill, MA: Sloan Work and Family Research Network.

Barnett, Rosalind Chait and Karen C. Gareis, 2000. 'Reduced-Hours Employment. The Relationship Between Difficulty of Trade-Offs and Quality of Life.' Work and Occupations 27(2): 168-187. doi: 10.1177/0730888400027002003.

_, 2002 . 'Full-Time and Reduced-Hours Work Schedules and Marital Quality. A Study of Female Physicians with Young Children.' Work and Occupations 29(3): 364-379. doi: 10.1177/0730888402029003005.

Barnett, Rosalind Chait and Douglas T. Hall, 2001. 'How to Use Reduced Hours to Win the War for Talent.' Organizational Dynamics 29(3): 192-210. doi: 10.1016/S0090-2616(01)00024-9.

Bäck-Wiklund, Margareta, Tanja van der Lippe, Laura den Dulk, and Anneke van Doorne-Huiskes, 2011. Quality of Life and Work in Europe. Theory, Practice, and Policy. Houndmills, Basingstoke: Palgrave Macmillan. doi: $10.1057 / 9780230299443$. 
Beham, Barbara and Sonja Drobnič, 2010. 'Satisfaction with Work-Family Balance among German Office Workers.' Journal of Managerial Psychology 25(6): 669-689. doi: 10.1108/02683941011056987.

Beham, Barbara, Sonja Drobnič, and Patrick Präg, 2011. 'Work Demands and Resources and the Work-Family Interface. Testing a Salience Model on German Service Sector Employees.' Journal of Vocational Behavior 78(1): 110-122. doi: 10.1016/j.jvb.2010.07.008.

_, 2014. 'The Work-Family Interface of Service Sector Workers. A Comparison of Work Resources and Professional Status across Five European Countries.' Applied Psychology 63(1): 29-61. doi: 10.1111/apps.12012.

Beham, Barbara, Patrick Präg, and Sonja Drobnič, 2010. 'Balance zwischen Erwerbstätigkeit und Familienleben. Eine vergleichende Studie unter Eltern in vier europäischen Ländern.' In Schmidt, Matthias and Christoph Schank, eds., Die Metropolregion Berlin vor demografischen und gesellschaftlichen Herausforderungen, pp. 81-104. Munich: Hampp. doi: 10.31235/osf.io/vq4ek.

Bielenski, Harald, Alexandra Wagner, and Gerhard Bosch, 2002. Working Time Preferences in Sixteen European Countries. Dublin: European Foundation for the Improvement of Living and Working Conditions.

Brislin, Richard W., 1986. 'The Wording and Translation of Research Instruments.' In Berry, John W. and Walter J. Lonner, eds., Field Methods in Cross-Cultural Research, pp. 137-164. Beverly Hills, CA: Sage.

Buddelmeyer, Hielke, Gilles Mourre, and Melanie Ward, 2005. 'Recent Developments in Part-Time Work in EU Countries. Trends and Policy.' In Gómez-Salvador, Ramón, Ana Lamo, Barbara Petrongolo, Melanie Ward, and Etienne Wasmer, eds., Labor Supply and Incentives to Work in Europe, pp. 273-308. Cheltenham: Elgar. doi: 10.4337/9781845425623.00022.

Carlson, Dawn S., Joseph G. Grzywacz, and Suzanne Zivnuska, 2009. 'Is Work-Family Balance More than Conflict and Enrichment?' Human Relations 62(10): 1459-1486. doi: 10.1177/0018726709336500.

Clark, Sue Campbell, 2000. 'Work-Family Border Theory. A New Theory of Work-Family Balance.' Human Relations 53(6): 747-770. doi: 10.1177/0018726700536001.

Clarke, Maribeth C., Laura C. Koch, and E. Jeffrey Hill, 2004. 'The WorkFamily Interface: Differentiating Balance and Fit.' Family and Consumer Sciences Research Journal 33(2): 121-140. doi: 10.1177/1077727X04269610.

Corwin, Vivien, Thomas B. Lawrence, and Peter J. Frost, 2001. 'Five Strategies of Successful Part-Time Work.' Harvard Business Review 79(7): 121-127. 
Dikkers, Josje, Sabine Geurts, Laura den Dulk, Bram Peper, and Michiel Kompier, 2004. 'Relations among Work-Home Culture, the Utilization of Work-Home Arrangements, and Work-Home Interference.' International Journal of Stress Management 11(4): 323-345. doi: 10.1037/10725245.11.4.323.

DiRenzo, Marco S., Jeffrey H. Greenhaus, and Christy H. Weer, 2011. 'Job Level, Demands, and Resources as Antecedents of Work-Family Conflict.' Journal of Vocational Behavior 78(2): 305-314. doi: 10.1016/j.jvb.2010.10.002.

Drobnič, Sonja and Ana M. Guillén Rodríguez, 2011. 'Tensions Between Work and Home. Job Quality and Working Conditions in the Institutional Contexts of Germany and Spain.' Social Politics 18(2): 232-268. doi: $10.1093 / \mathrm{sp} / \mathrm{jxr} 008$.

Drobnič, Sonja, Barbara Beham, and Patrick Präg, 2010. 'Good Job, Good Life? Working Conditions and Quality of Life in Europe.' Social Indicators Research 99(2): 205-225. doi: 10.1007/s11205-010-9586-7.

Eby, Lillian T., Wendy J. Casper, Angie Lockwood, Chris Bordeaux, and Andi Brinley, 2005. 'Work and Family Research in IO/OB. Content Analysis and Review of the Literature (1980-2002).' Journal of Vocational Behavior 66(1): 124-197. doi: 10.1016/j.jvb.2003.11.003.

Edwards, Jeffrey R. and Nancy P. Rothbard, 2000. 'Mechanisms Linking Work and Family. Clarifying the Relationship Between Work and Family Constructs.' Academy of Management Review 25(1): 178-199. doi: 10.5465/amr.2000.2791609.

Erikson, Robert and John H. Goldthorpe, 1992. The Constant Flux. A Study of Class Mobility in Industrial Societies. Oxford: Clarendon.

Eurostat, 2009. Reconciliation between Work, Private, and Family Life in the European Union. Luxembourg: Office for Official Publications of the European Communities. doi: 10.2785/30167.

Frone, Michael R., Marcia Russell, and M. Lynne Cooper, 1992. 'Antecedents and Outcomes of Work-Family Conflict. Testing a Model of the Work-Family Interface.' Journal of Applied Psychology 77(1): 65-78. doi: 10.1037/00219010.77.1.65.

Gasparini, Giovanni, Agnès Parent-Thirion, Mia Latta, and Matthieu de Nanteuil, 2000. Full-Time or Part-Time Work. Realities and Options. Dublin: European Foundation for the Improvement of Living and Working Conditions. 
Gelman, Andrew and Jennifer Hill, 2007. Data Analysis Using Regression and Multilevel/Hierarchical Models. Cambridge: Cambridge University Press. doi: 10.1017/CBO9780511790942.

Goode, William J., 1960. 'A Theory of Role Strain.' American Sociological Review 25(4): 483-496. doi: 10.2307/2092933.

Greenhaus, Jeffrey H. and Tammy D. Allen, 2011. 'Work-Family Balance. A Review and Extension of the Literature.' In Quick, James Campbell and Lois E. Tetrick, eds., Handbook of Occupational Health Psychology, pp. 165183. Washington, DC: APA, 2nd edition.

Greenhaus, Jeffrey H. and Nicholas J. Beutell, 1985. 'Sources of Conflict between Work and Family Roles.' Academy of Management Review 10(1): 76-88. doi: 10.5465/AMR.1985.4277352.

Grzywacz, Joseph G. and Dawn S. Carlson, 2007. 'Conceptualizing Work-Family Balance. Implications for Practice and Research.' Advances in Developing Human Resources 9(4): 455-471. doi: $10.1177 / 1523422307305487$.

Hakim, Catherine, 2004. Key Issues in Women's Work. Female Diversity and the Polarisation of Women's Employment. London: Routledge, 2nd edition. doi: $10.4324 / 9781843146148$.

Higgins, Christopher A., Linda E. Duxbury, and Karen Lea Johnson, 2000. 'Part-Time Work for Women. Does It Really Help Balance Work and Family?' Human Resource Management 39(1): 17-32. doi: 10.1002/(SICI)1099050X(200021)39:1¡17.

Hill, E. Jeffrey, Vjollca K. Märtinson, and Maria Ferris, 2004a. 'New-Concept Part-Time Employment as a Work-Family Adaptive Strategy for Women Professionals with Small Children.' Family Relations 53(3): 282-292. doi: 10.1111/j.0022-2445.2004.0004.x.

Hill, E. Jeffrey, Vjollca K. Märtinson, Maria Ferris, and Robin Zenger Baker, 2004b. 'Beyond the Mommy Track. The Influence of New-Concept Part-Time Work for Professional Women on Work and Family.' Journal of Family and Economic Issues 25(1): 121-136. doi: 10.1023/B:JEEI.0000016726.06264.91.

Hochschild, Arlie Russell, 1997. The Time Bind. When Work Becomes Home and Home Becomes Work. New York: Metropolitan/Holt.

ILO, 1994. Convention 175 and Recommendation 182 Concerning Part-Time Work. Geneva: International Labor Organization. 
Kalleberg, Arne L., 2000. 'Nonstandard Employment Relations. Part-Time, Temporary, and Contract Work.' Annual Review of Sociology 26: 341-365. doi: 10.1146/annurev.soc.26.1.341.

Kossek, Ellen Ernst, Brenda A. Lautsch, and Susan C. Eaton, 2006. 'Telecommuting, Control, and Boundary Management. Correlates of Policy Use and Practice, Job Control, and Work-Family Effectiveness.' Journal of Vocational Behavior 68(2): 347-367. doi: 10.1016/j.jvb.2005.07.002.

Lautsch, Brenda A. and Maureen A. Scully, 2007. 'Restructuring Time. Implications of Work Hours Reductions for the Working Class.' Human Relations 60(5): 719-743. doi: 10.1177/0018726707079199.

Lawrence, Thomas B. and Vivien Corwin, 2003. 'Being There. The Acceptance and Marginalization of Part-Time Professional Employees.' Journal of Organizational Behavior 24(8): 923-943. doi: 10.1002/job.229.

Lee, Mary Dean, Shelley M. MacDermid, Margaret L. Williams, Michelle L. Buck, and Sharon Leiba-O'Sullivan, 2002. 'Contextual Factors in the Success of Reduced-Load Work Arrangements among Managers and Professionals.' Human Resource Management 41(2): 209-223. doi: 10.1002/hrm.10032.

Lewis, Suzan, Richenda Gambles, and Rhona Rapoport, 2007. 'The Constraints of a 'Work-Life Balance' Approach. An International Perspective.' International Journal of Human Resource Management 18(3): 360-373. doi: $10.1080 / 09585190601165577$.

Lyonette, Clare, Beate Baldauf, and Heike Behle, 2010. 'Quality' Part-Time Work. A Review of the Evidence. London: Government Equalities Office.

Marks, Stephen R. and Shelley M. MacDermid, 1996. 'Multiple Roles and the Self. A Theory of Role Balance.' Journal of Marriage and Family 58(2): 417-432. doi: 10.2307/353506.

Martin, James E. and Robert R. Sinclair, 2007. 'A Typology of the Part-Time Workforce. Differences on Job Attitudes and Turnover.' Journal of Occupational and Organizational Psychology 80(2): 301-319. doi: 10.1348/096317906X113833.

Massarelli, Nicola and Monika Wozowczyk, 2010. 'European Union Labor Force Survey. Annual Results 2009.' Eurostat Data in Focus 35/2010: 1-8.

McGinnity, Frances and Emma Calvert, 2009. 'Work-Life Conflict and Social Inequality in Western Europe.' Social Indicators Research 93(3): 489-508. doi: $10.1007 /$ s11205-008-9433-2. 
Mills, Melinda and Kadri Täht, 2011. 'Nonstandard Work Schedules and Partnership Quality. Quantitative and Qualitative Findings.' Journal of Marriage and Family 72(4): 860-875. doi: 10.1111/j.1741-3737.2010.00735.x.

Präg, Patrick, Maria das Dores Guerreiro, Jouko Nätti, Michael Brookes, and Laura den Dulk, 2011. 'Quality of Work and Quality of Life of Service Sector Workers. Cross-National Variations in Eight European Countries.' In BäckWiklund, Margareta, Tanja Van der Lippe, Laura Den Dulk, and Anneke Van Doorne-Huiskes, eds., Quality of Work and Life. Theory, Practice, and Policy, pp. 77-94. Basingstoke: Palgrave Macmillan. doi: 10.1057/9780230299443_5.

Präg, Patrick, Steffen Mau, and Roland Verwiebe, 2010. 'Quality of Life.' In Mau, Steffen and Roland Verwiebe, eds., European Societies. Mapping Structure and Change, pp. 225-260. Bristol: Policy. doi: 10.31235/osf.io/a8qhf.

Ransome, Paul, 2007. 'Conceptualizing Boundaries between 'Life' and 'Work'.' International Journal of Human Resource Management 18(3): 374-386. doi: 10.1080/09585190601167425.

Raudenbush, Stephen W. and Anthony S. Bryk, 2002. Hierarchical Linear Models. Applications and Data Analysis Methods. Thousand Oaks, CA: Sage, 2nd edition.

Sanne, Bjarte, Steffen Torp, Arnstein Mykletun, and Alv A. Dahl, 2005. 'The Swedish Demand-Control-Support Questionnaire (DCSQ). Factor Structure, Item Analyses, and Internal Consistency in a Large Population.' Scandinavian Journal of Social Medicine 33(3): 166-174. doi: 10.1080/14034940410019217.

Sándor, Eszter, 2011. Part-Time Work in Europe. Dublin: European Foundation for the Improvement of Living and Working Conditions. doi: $10.2806 / 116$.

Spector, Paul E., 2002. 'Research Methods in Industrial and Organizational Psychology. Data Collection and Data Analysis with Special Consideration to International Issues.' In Anderson, Neil, Deniz S. Ones, Handan Kepir Sinangil, and Chockalingam Viswesvaran, eds., Handbook of Industrial, Work, and Organizational Psychology, volume 1 (Personnel Psychology), pp. 10-26. London: Sage. doi: 10.4135/9781848608320.n2.

Stone-Romero, Eugene F. and Patrick J. Rosopa, 2007. 'The Relative Validity of Inferences About Mediation as a Function of Research Design Characteristics.' Organizational Research Methods 11(2): 326-352. doi: $10.1177 / 1094428107300342$. 
Sverke, Magnus, Johnny Hellgren, Katharina Näswall, Antonio Chirumbolo, Hans de Witte, and Sjoerd Goslinga, 2004. Job Insecurity and Union Membership. European Unions in the Wake of Flexible Production. Brussels: Peter Lang.

Szücs, Stefan, Drobnič Sonja, Laura Den Dulk, and Roland Verwiebe, 2011. 'Quality of Life and Satisfaction with the Work-Life Balance.' In BäckWiklund, Margareta, Tanja Van der Lippe, Laura Den Dulk, and Anneke Van Doorne-Huiskes, eds., Quality of Work and Life. Theory, Practice, and Policy, pp. 95-117. Houndmills, Basingstoke: Palgrave Macmillan.

Tausig, Mark and Rudy Fenwick, 2001. 'Unbinding Time. Alternate Work Schedules and Work-Life Balance.' Journal of Family and Economic Issues 22(2): 101-119. doi: 10.1023/A:1016626028720.

Tilly, Chris, 1996. Half a Job. Bad and Good Part-Time Jobs in a Changing Labor Market. Philadelphia, PA: Temple University Press.

Tomlinson, Jennifer, 2007. 'Employment Regulation, Welfare, and Gender Regimes. A Comparative Analysis of Women's Working-Time Patterns and Work-Life Balance in the UK and the US.' International Journal of Human Resource Management 18(3): 401-415. doi: 10.1080/09585190601167466.

Treas, Judith and Sonja Drobnič, 2010. Dividing the Domestic. Men, Women, and Household Work in Cross-National Perspective. Stanford, CA: Stanford University Press. doi: 10.11126/stanford/9780804763578.001.0001.

Valcour, Monique P., 2007. 'Work-Based Resources as Moderators of the Relationship between Work Hours and Satisfaction with Work-Family Balance.' Journal of Applied Psychology 92(6): 1512-1523. doi: 10.1037/00219010.92.6.1512.

Van Rijswijk, Karen, Marrie H. J. Bekker, Christel G. Rutte, and Marcel A. Croon, 2004. 'The Relationships Among Part-Time Work, Work-Family Interference, and Wellbeing.' Journal of Occupational Health Psychology 9(4): 286-295. doi: 10.1037/1076-8998.9.4.286.

Visser, Jelle, 2002. 'The First Part-Time Economy in the World. A Model to Be Followed?' Journal of European Social Policy 12(1): 23-42. doi: $10.1177 / 0952872002012001561$.

Walsh, Janet, 2007. 'Experiencing Part-Time Work. Temporal Tensions, Social Relations, and the Work-Family Interface.' British Journal of Industrial Relations 45(1): 155-177. doi: 10.1111/j.1467-8543.2007.00606.x. 
Walters, Sally, 2005. 'Making the Best of a Bad Job? Female Part-Timers' Orientations and Attitudes to Work.' Gender, Work, and Organization 12(3): 193-216. doi: 10.1111/j.1468-0432.2005.00270.x.

Webber, Gretchen and Christine Williams, 2008. 'Mothers in 'Good' and 'Bad' Part-Time Jobs. Different Problems, Same Results.' Gender and Society 22(6): 752-777. doi: 10.1177/0891243208325698.

Wilson, Kelly, Michelle Brown, and Christina Cregan, 2008. 'Job Quality and Flexible Practices. An Investigation of Employee Perceptions.' International Journal of Human Resource Management 19(3): 473-486. doi: 10.1080/09585190801895544.

Wittmer, Jenell L. S. and James E. Martin, 2011a. 'Effects of Scheduling Perceptions on Attitudes and Mobility in Different Part-Time Employee Types.' Journal of Vocational Behavior 78(1): 149-158. doi: 10.1016/j.jvb.2010.07.004.

__ , 2011b. 'Work and Personal Role Involvement of Part-Time Employees. Implications for Attitudes and Turnover Intentions.' Journal of Organizational Behavior 32(5): 767-787. doi: 10.1002/job.711. 